\title{
The role of oxidative phosphorylation in the generation of ATP in human spermatozoa
}

\author{
W. C. L. Ford and Anne Harrison \\ Department of Physiology \& Biochemistry, The University, Whiteknights, Reading RG6 $2 A J$, \\ U.K.
}

\begin{abstract}
Summary. Washed human spermatozoa had an endogenous oxygen uptake of $2 \cdot 14$ $\pm 0.17 \mathrm{nmol} \mathrm{O}_{2} / 10^{8}$ spermatozoa $/$ min (mean \pm s.e.m., $n=35$ ) which was stimulated by succinate $\left(V_{\max }=9.64 \pm 0.44 \mathrm{nmol} \mathrm{O}_{2} / 10^{8}\right.$ spermatozoa $\left./ \mathrm{min}\right)$ but not by other substrates. The ATP concentration in freshly washed spermatozoa was $12.18 \pm 0.54$ (s.e.m.) $\mathrm{nmol} / 10^{8}$ spermatozoa $(n=26)$ and was maintained for $2 \mathrm{~h}$ in the presence of $2 \mathrm{~mm}$-D-glucose but fell to $9.56 \pm 0.73$ (s.e.m.) $\mathrm{nmol} / 10^{8}$ spermatozoa $(n=13)$ in its absence. The presence of $2 \mu \mathrm{M}$-antimycin A, 2 $\mu \mathrm{M}$-rotenone, $0.4 \mu \mathrm{M}$-carbonyl cyanide $m$-chlorophenyl hydrazone or $8 \mu \mathrm{M}$ oligomycin caused the ATP concentration to fall to $<2 \mathrm{nmol} / 10^{8}$ spermatozoa but their effect was partly alleviated by $2 \mathrm{~mm}$-glucose. Sodium malonate $(5 \mathrm{~mm})$ prevented the stimulation of respiration by succinate but had no effect on the ATP concentration of the spermatozoa or their ability to produce ${ }^{14} \mathrm{CO}_{2}$ from $\left[\mathrm{U}-{ }^{14} \mathrm{C}\right.$ ]glucose.

The least active of the tricarboxylic acid cycle enzymes was 2-oxoglutarate dehydrogenase (EC 1.2.4.2) $\left(3.1 \pm 0.6\right.$ (s.e.m.) nmol substrate transformed $/ 10^{8}$ spermatozoa/h $(n=4)$. Cytochrome c oxidase (EC 1.9.3.1) was much less active than in rat spermatozoa $(22.3 \pm 6.0$ (s.e.m., $n=4)$ and $615 \pm 87(n=4) \mathrm{nmol}$ transformed $/ 10^{8}$ spermatozoa $/ \mathrm{min}$ ).

It is concluded that human spermatozoa can obtain ATP by the respiration of endogenous substrate but the substrates and metabolic pathways involved remain obscure.
\end{abstract}

\section{Introduction}

The contribution of oxidative phosphorylation to the generation of ATP in human spermatozoa is unclear. These cells exhibit a high rate of aerobic glycolysis and substrate level phosphorylation can completely fulfil their energy demands when glucose or fructose is available (Macleod, 1941a; Peterson \& Freund, 1969, 1970). Human spermatozoa contain cytochromes a, b and c (Mann, 1951) and, in spite of some early controversy (Macleod, 1941a, 1943), it is now clear that they take up oxygen (Nevo, 1966; Murdoch \& White, 1968; Peterson \& Freund, 1968; Eliasson, 1970; Hicks, Martinez, Pedron \& Rosado, 1972; Storey, 1978) and can oxidize acetate, pyruvate, glucose or succinate to $\mathrm{CO}_{2}$ (Terner, 1960; Peterson \& Freund, 1968; Ford, Harrison, Takkar \& Waites, 1979). Although it has been reported that respiration was stimulated by lactate, citrate (Hicks et al., 1972), glycerol or sorbitol (Murdoch \& White, 1968), succinate has most often been the only substrate which has stimulated the uptake of oxygen (Macleod, 1943; Peterson \& Freund, 1970, 1974; Storey, 1978). Macleod (1941b, 1943) found 
that washed human spermatozoa required a glycolytic substrate to remain motile even under aerobic conditions when succinate was present. The ATP concentration in the cells fell rapidly in the absence of glucose but could be partly restored by the subsequent addition of the sugar although its decline was accelerated by dinitrophenol (Peterson \& Freund, 1970). By contrast, Nevo (1966) found that washed human spermatozoa remained motile without added substrate under aerobic but not anaerobic conditions. Suter, Chow \& Martin (1979) reported that the ATP content in the spermatozoa declined only slowly during a $3 \mathrm{~h}$ aerobic incubation without added substrate but that oligomycin produced a rapid decline in both the ATP concentration and motility although these effects were prevented by $5 \mathrm{~mm}$-glucose. Respiration was sufficient to maintain the energy charge of washed human spermatozoa until they were stimulated by the addition of $10 \mathrm{~mm}$-caffeine, although energy charge was maintained even then if $10 \mathrm{~mm}$-glucose was present (Chulavatnatol \& Haesungcharern, 1977). The endogenous respiration of washed human spermatozoa was inhibited by oligomycin and stimulated by bis(hexafluoroacetonyl acetone), suggesting that it is tightly coupled to ATP synthesis (Storey, 1978).

We have studied the effect of some respiratory and metabolic inhibitors to confirm the role of oxidative phosphorylation in providing energy for human spermatozoa and have measured the activities of the tricarboxylic acid cycle enzymes in an attempt to discover which limits the rate of respiration in these cells.

\section{Materials and Methods}

\section{Spermatozoa}

Ejaculates collected by masturbation were supplied by student volunteers who were free from urogenital infections. Spermatozoa were separated from the seminal plasma $1-3 \mathrm{~h}$ after collection by centrifugation through a layer of Ficoll (Harrison, 1976). The Ficoll solution was dialysed overnight against a large volume of PBS buffer (Edwards, Dacheux \& Waites, 1976) before use. The spermatozoa were resuspended in PBS buffer and their concentration was counted in two samples using a haemocytometer.

\section{Oxygen electrode experiments}

The oxygen electrode (Rank Bros., High Street, Bottisham, Cambridge CB5 9DA, U.K.) was calibrated by the addition of sodium dithionite to air-saturated water. About $60 \times 10^{6}$ spermatozoa suspended in $0.3 \mathrm{ml}$ PBS buffer were stirred vigorously in the reaction chamber at $35^{\circ} \mathrm{C}$ and substrates or inhibitors were added from microsyringes. The apparent kinetic constants for succinate oxidation were calculated by the method of Wilkinson (1961).

\section{Incubations}

Spermatozoa $\left(0.71 \pm 0.053 \times 10^{8}\right.$, mean \pm s.e.m., $\left.n=11\right)$ suspended in $1.0 \mathrm{ml}$ PBS buffer were incubated for $2 \mathrm{~h}$ at $35^{\circ} \mathrm{C}$ in $10 \mathrm{ml}$ glass conical flasks sealed with rubber caps (Suba Seal: Gallenkamp) in a shaking water bath. The first series of incubations contained 2 mM-D-glucose, $2 \mu \mathrm{M}$-antimycin A, $2 \mu \mathrm{M}$-rotenone, $0.4 \mu \mathrm{M}$-carbonyl cyanide $m$-chlorophenyl hydrazone (CCCP), $8 \mu \mathrm{M}$-oligomycin or one of the inhibitors plus 2 mM-glucose, $2 \mu \mathrm{M}$-rotenone +10 mM-sodium succinate or no additions. The second series contained $2 \mathrm{mM}-\mathrm{D}-\left[\mathrm{U}-{ }^{14} \mathrm{C}\right] \mathrm{glucose}$ (sp. act. $0.5 \mathrm{Ci} / \mathrm{mol}$ ), $5 \mathrm{~mm}$-sodium malonate, $0.2 \mathrm{~mm}$-sodium arsenite, one of the inhibitors plus 2 $\mathrm{mM}-\left[\mathrm{U}-{ }^{14} \mathrm{C}\right]$ glucose or no additions. The reaction was stopped by the addition of $0.5 \mathrm{ml} 10 \%$ (w/v) perchloric acid. Each series of incubations included flasks which were acidified at zero time. Subsequent manipulations and the collection of ${ }^{14} \mathrm{CO}_{2}$ were carried out as described previously (Ford \& Waites, 1978). Motility was scored as the percentage of spermatozoa which 
were progressively motile and was assessed subjectively with a phase-contrast microscope ( $\times 400$ magnification).

\section{Metabolite assays}

Lactate and ATP were measured as described by Hohorst (1963) and Williamson \& Corkey (1969) respectively.

\section{Measurement of enzyme activities}

Pellets of washed spermatozoa prepared as described above were mixed with an equal volume of $50 \%(\mathrm{v} / \mathrm{v})$ aqueous glycerol. The slurry was separated into small portions and stored under liquid nitrogen. To prepare the material for assay it was thawed and mixed with 100-200 times its own volume of ice-cold $10 \mathrm{~mm}$-potassium phosphate buffer ( $\mathrm{pH} 7.4$ at about $20^{\circ} \mathrm{C}$ ). For all the assays except that for NADP-linked isocitrate dehydrogenase (EC 1.1.1.42) and cytochrome oxidase (EC 1.9 .3 .1$) 0.1 \%(\mathrm{v} / \mathrm{v})$ Triton $\mathrm{X}-100$ was present in the assay medium. The homogenates used for the assay of 2-oxoglutarate dehydrogenase (EC 1.2.4.2) and cytochrome c oxidase were sonicated for 6 bursts of $10 \mathrm{sec}(100 \mathrm{~W}, 6-8 \mu \mathrm{m}$ peak to peak) with a $20 \mathrm{sec}$ cooling period between each burst. Protein concentration was measured by the method of Warburg \& Christian as described by Dawson, Elliott, Elliott \& Jones (1969). The spermatozoa were dissolved in $2 \mathrm{M}-\mathrm{NaOH}$ by heating at $60^{\circ} \mathrm{C}$ and an equal volume of $2 \mathrm{M}-\mathrm{HCl}$ was added before the absorbance readings were made. To permit comparison the same enzymes in spermatozoa from the cauda epididymidis of rats were measured by identical procedures. All assays were carried out at $25^{\circ} \mathrm{C}$ and the $\mathrm{pH}$ of the buffers was adjusted at room temperature (about $20^{\circ} \mathrm{C}$ ). The methods used for individual enzymes were as follows:

Glutamate dehydrogenase (EC 1.4.1.3) was measured by the method of Schmidt (1963);

Citrate synthase (EC 4.1.3.7) was measured at pH $8 \cdot 1$ as described by Alp, Newsholme \& Zammit (1976) except that the final volume was $1.0 \mathrm{ml}$;

Isocitrate dehydrogenase $(N A D P)$ was measured by a modification of the procedure of Cleland, Thompson \& Bardon (1969). Cuvettes contained $50 \mathrm{~mm}$-triethanolamine pH 7.4, 10 mM- $\mathrm{MgCl}_{2}, 5 \mathrm{mM}$-EDTA, $7.5 \mathrm{mM}-\mathrm{KCl}, 0.59 \mathrm{mM}^{-N A D P}{ }^{+}, 0.3 \mathrm{~mm}$-dithiothreitol plus lysed spermatozoa in a total volume of $2.0 \mathrm{ml}$. The reaction was started by the addition of 2.5 MM-DL-isocitrate;

Isocitrate dehydrogenase (NAD) (EC 1.1.1.41) was measured as described by Plaut (1969);

2-Oxoglutarate dehydrogenase was measured by the method of Read, Crabtree \& Smith (1977) except that the NADH concentration was monitored fluorometrically;

Fumarase (EC 4.2.1.2) was measured as described by Hill \& Bradshaw (1969);

Malate dehydrogenase (EC 1.1.1.37) was measured by the method of Bergemeyer \& Bernt (1963);

Carnitine acetyl transferase (EC 2.3.1.7) was measured by a procedure adapted from a method for carnitine analysis (Pearson, Chase \& Tubbs, 1969). The buffer was 100 mM-Tris-HCl, pH 8.1, $0.3 \mathrm{~mm}$-acetyl CoA, $1 \mathrm{mm-EDTA}, 2.5 \mathrm{~mm}$-DL-carnitine and 0.1 mM-5,5'-dithiobis-(2-nitrobenzoic acid) DTNB. The reaction was started by the addition of lysed spermatozoa and the increase in absorbance at $412 \mathrm{~nm}$ was measured. A blank lacking carnitine was run for each sample. The rate remained linear for 1-2 min;

Cytochrome oxidase was measured as described by Yonetani (1967).

\section{Reagents}

Enzymes and biochemicals were obtained from Boehringer Corp., Lewes BN7 1LG, U.K., or Sigma Chemical Co. Ltd, Poole BH17 7NM, U.K. D[U- ${ }^{14}$ C $]$ Glucose was supplied by the 
Radiochemical Centre, Amersham, HP7 9LL, U.K. Other reagents were purchased from BDH Chemicals Ltd, Poole BH12 4NN, U.K., or Fisons Scientific Apparatus, Loughborough LE11 OR9, U.K.

\section{Results}

The endogenous oxygen uptake of washed human spermatozoa measured in the oxygen electrode was $2 \cdot 14 \pm 0 \cdot 17$ (mean \pm s.e.m. of 35 observations on 8 sets of pooled ejaculates) with a range of $0.77-4.72 \mathrm{nmol} \mathrm{O}_{2} / 10^{8}$ spermatozoa $/ \mathrm{min}$. The uptake of oxygen was not stimulated by the sodium salts of rac-glycerol-3-phosphate, lactate, octanoate, acetate or pyruvate + malate but was markedly increased by succinate. The $V_{\max }$ for the stimulation of oxygen uptake by succinate was $9.64 \pm 0.44 \mathrm{nmol} \mathrm{O} / 10^{8}$ spermatozoa/min with an apparent $K_{\mathrm{m}}$ of $0.62 \pm 0.094$ $\mathrm{mM}$ for succinate. These values were calculated from measurements on a single set of pooled ejaculates and the standard error would be greater if different ejaculates were compared. The oxygen uptake was not further stimulated by the addition of $5 \mathrm{~mm}$-sodium pyruvate. The endogenous oxygen uptake was markedly inhibited by $2.2 \mu \mathrm{M}$-rotenone; this inhibitor did not affect the oxidation of succinate but $0.2 \mu \mathrm{M}$-antimycin $\mathrm{A}$ decreased both the endogenous and succinate-stimulated oxygen uptake (Text-fig. 1a). Sodium malonate (5mM) eliminated the stimulation of oxygen uptake by $5 \mathrm{~mm}$-sodium succinate but $15 \mathrm{~mm}$-sodium malonate did not decrease the residual oxygen uptake significantly below the endogenous rate (Text-fig. 1b). Neither CCCP nor oligomycin had a significant effect on oxygen uptake under these conditions but $0.4 \mu \mathrm{M}$-CCCP increased the production of ${ }^{14} \mathrm{CO}_{2}$ from $\left[\mathrm{U}-{ }^{14} \mathrm{C}\right]$ glucose by $49 \%$ in a typical experiment.

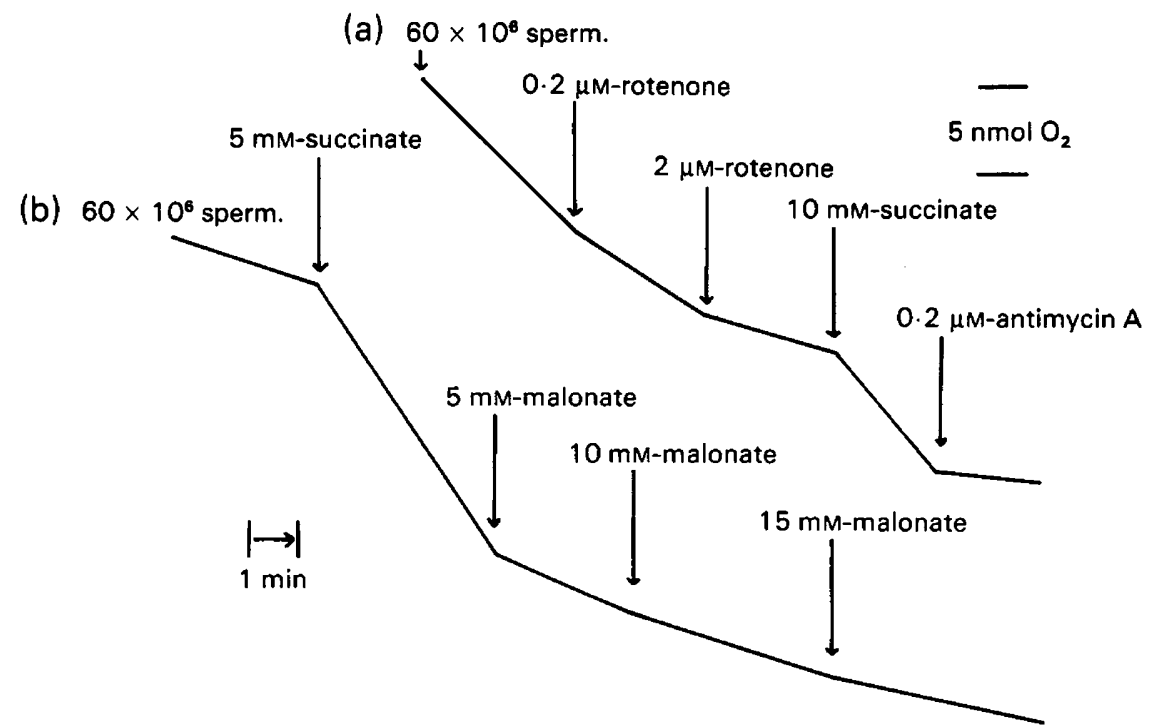

Text-fig. 1. Oxygen electrode traces to illustrate the effect of sodium succinate and of some inhibitors on the oxygen uptake of human spermatozoa suspended in $0.30 \mathrm{ml}$ PBS buffer at $35^{\circ} \mathrm{C}$.

The ATP concentration in washed human spermatozoa declined by $20 \%(P<0.01)$ when incubated for $2 \mathrm{~h}$ at $35^{\circ} \mathrm{C}$ in phosphate-buffered physiological saline with no added substrate (Table 1). However, the ATP concentration dropped to very low values when $2 \mu \mathrm{M}$-antimycin A, $2 \mu \mathrm{M}$-rotenone, $0.4 \mu \mathrm{M}$-CCCP or $8 \mu \mathrm{M}$-oligomycin were present. In spermatozoa incubated with 
2 mM-D-glucose the ATP concentration did not change during the $2 \mathrm{~h}$ incubation and the effects of the inhibitors were at least partly alleviated; however, $10 \mathrm{mM}$-succinate did not reverse the effect of $2 \mu \mathrm{M}$-rotenone on the ATP concentration in the spermatozoa (Table 1).

Table 1. The effect of respiratory inhibitors and D-glucose on the ATP concentration in washed human spermatozoa after a $2 \mathrm{~h}$ incubation at $35^{\circ} \mathrm{C}$

\begin{tabular}{|c|c|c|c|}
\hline \multirow[b]{2}{*}{ Inhibitor } & \multicolumn{3}{|c|}{ ATP conc. (nmol/108 spermatozoa) } \\
\hline & No added substrate & 2 mM-D-Glucose & $10 \mathrm{mM}$-Sodium succinate \\
\hline None & $\begin{array}{c}9.56 \pm 0.73 \\
(13)\end{array}$ & $\begin{array}{c}12 \cdot 25 \pm 0.894 \dagger \\
(10)\end{array}$ & - \\
\hline $2 \mu \mathrm{M}$-Antimycin A & $1.11+0.407^{* * *}$ & $6.95 \pm 0.601^{* *} \ddagger$ & - \\
\hline $2 \mu \mathrm{M}-$ Rotenone & $0.90 \pm \frac{(4)}{0.141^{* * *}}$ & $\begin{array}{c}5.95(7 \cdot 13,4 \cdot 76) \\
(2)\end{array}$ & $0.77 \underset{(5)}{ \pm 0.21}$ \\
\hline $0.4 \mu \mathrm{M}-\mathrm{CCCP}$ & $2.55(2.42,2.67)$ & $11.88 \pm 0.644$ & - \\
\hline $8 \mu \mathrm{M}$-Oligomycin & $0.45 \pm 0.29^{* * *}$ & $9 \cdot 19 \pm 0.37 \ddagger$ & - \\
\hline
\end{tabular}

Values are mean \pm s.e.m. for the no. of tests in parentheses.

The ATP concentration at the start of the incubation was $12.18 \pm 0.054 \mathrm{nmol} / 10^{8}$ spermatozoa $(n=28)$.

Values significantly different ( $t$ test) from those with the same substrate conditions but no inhibitor: ${ }^{*} P<0.05,{ }^{* *} P<0.01,{ }^{* *} P<0.001$.

Values significantly different from those with the same inhibitor but no substrate: $\dagger P<0.05$; $\ddagger P<0.001$.

The motility of the spermatozoa was monitored during one experiment. Between 40 and $50 \%$ of the cells were progressively motile at zero time and this proportion was maintained for $2 \mathrm{~h}$ when $2 \mathrm{mM}$-D-glucose was present. When no substrate was added or with $2 \mathrm{~mm}$-glucose in the presence of $2 \mu \mathrm{M}$-rotenone or $2 \mu \mathrm{M}$-antimycin A there was no change in motility for the first hour but it then declined until about $25 \%$ of the spermatozoa were still motile after $2 \mathrm{~h}$. When the inhibitors were added in the absence of glucose, $<10 \%$ of the spermatozoa were motile after 30 min and none was motile after $2 \mathrm{~h}$.

The production of lactate from $2 \mathrm{mM}-\mathrm{D}$-glucose may have been slightly increased in the presence of $2 \mu \mathrm{M}$-antimycin A, $2 \mu \mathrm{M}$-rotenone or $0.4 \mu \mathrm{M}$-CCCP. When the data were pooled in such a way that a paired $t$ test could be used, lactate production in the controls was $0.82 \pm 0.08$ $\mu \mathrm{mol} / 10^{8}$ spermatozoa $/ 2 \mathrm{~h}$ while that in the presence of the inhibitor was $0.98 \pm 0.042$ $\mu \mathrm{mol} / 10^{8}$ spermatozoa $/ 2 \mathrm{~h}(n=8)(P<0.05)$. The difference was not statistically significant $(t$ test) when all the available control data were included and a paired test could not be used.

Sodium malonate $(5 \mathrm{~mm})$ had no effect on the ability of the spermatozoa to maintain their ATP concentration or to metabolize glucose (Table 2). By contrast, in the presence of 0.2 mM-sodium arsenite the spermatozoa oxidized less glucose to $\mathrm{CO}_{2}$ and the ATP concentration was always less than in controls although the statistical significance of the latter change is doubtful $(P<0.07$, paired $t$ test). The conversion of glucose to lactate was unimpaired.

The specific activities of NADP- and NAD-linked isocitrate dehydrogenase, citrate synthase and 2-oxoglutarate dehydrogenase were similar in human ejaculated spermatozoa and rat epididymal spermatozoa when expressed per mg protein. Human spermatozoa contained more fumarase and malate dehydrogenase but less cytochrome $c$ oxidase than did rat spermatozoa. These relative values changed when the data were expressed per $10^{8}$ spermatozoa because of the larger size of the rat cells. The least active enzymes were isocitrate dehydrogenase (NADP), isocitrate dehydrogenase (NAD) and 2-oxoglutarate dehydrogenase in spermatozoa from either 
Table 2. The effect of $5 \mathrm{~mm}$-sodium malonate or $0.2 \mathrm{~mm}$-sodium arsenite on the metabolism of $2 \mathrm{mM}-\mathrm{D}-\left[\mathrm{U}^{14}-\mathrm{C}\right] \mathrm{glucose}$ and the ATP content of washed human spermatozoa after incubation for $2 \mathrm{~h}$ at $35^{\circ} \mathrm{C}$

\begin{tabular}{|c|c|c|c|c|}
\hline & Substrate & $\begin{array}{l}\mathrm{ATP}\left(\mathrm{nmol} / 10^{8}\right. \\
\text { spermatozoa) }\end{array}$ & $\begin{array}{c}\text { Lactate } \\
\text { ( } \mu \text { mol produced } / 10^{8} \\
\text { spermatozoa) }\end{array}$ & $\begin{array}{c}\text { Glucose converted } \\
\text { to }{ }^{14} \mathrm{CO}_{2} \\
\text { (nmol/10 } 10^{8} \text { spermatozoa) }\end{array}$ \\
\hline Control & $\begin{array}{l}\text { No addition } \\
\text { Glucose }\end{array}$ & $\begin{array}{r}9.82 \pm 2.59(7) \\
14.34 \pm 2.77(6)\end{array}$ & $0.89 \pm 0.067(6)$ & $7.71 \pm 1.04(6)$ \\
\hline \multirow[t]{2}{*}{ Sodium malonate } & No addition & $11.28 \pm 2.65(5)$ & & \\
\hline & Glucose & $\begin{array}{r}16.74 \pm 2.38(4) \\
7.17+3.34(4)\end{array}$ & $1.00 \pm 0.057(4)$ & $10.35 \pm 1.66(4)$ \\
\hline Sodium arsenite & Glucose & $13.14 \pm 3.64(4)$ & $1.00 \pm 0.104(4)^{*}$ & $4.54 \pm 1.53(4)^{* *}$ \\
\hline
\end{tabular}

Values are mean \pm s.e.m. for the no. of observations in parentheses.

Significantly different from the corresponding controls; ${ }^{*} P<0.05,{ }^{* *} P<0.01$ (paired $t$ test).

source but their activities were sufficient to account for the maximum observed flux through the cycle calculated from the oxygen uptake in the presence of added substrate. Carnitine acetyl transferase was less active in human than in rat spermatozoa and glutamate dehydrogenase was not detected in the former cells (Table 3 ).

Table 3. The specific activity of some enzymes of the tricarboxylic acid cycle and related pathways in human ejaculated spermatozoa and spermatozoa from the cauda epididymidis of the rat

\begin{tabular}{|c|c|c|c|c|}
\hline \multirow[b]{3}{*}{ Enzyme } & \multicolumn{4}{|c|}{ Specific activity (nmol substrate transformed/min) } \\
\hline & \multicolumn{2}{|c|}{ Human ejaculated spermatozoa } & \multicolumn{2}{|c|}{ Rat epididymal spermatozoa } \\
\hline & /mg protein & $/ 10^{8}$ spermatozoa $\dagger$ & $/ \mathrm{mg}$ protein & $/ 10^{8}$ spermatozoa $\dagger$ \\
\hline Glutamate dehydrogenase & ND & ND & $42 \pm 2.8(4)$ & $1000 \pm 67$ \\
\hline $\begin{array}{l}\text { (NADP) } \\
\text { Isocitrate dehydrogenase }\end{array}$ & $5 \cdot 5 \pm 2 \cdot 91(8)$ & $17 \pm 9^{*}$ & $1.9 \pm 0.07(5)$ & $44 \pm 1 \cdot 7$ \\
\hline (NAD) & $4 \cdot 2 \pm 1 \cdot 29(3)$ & $13 \pm 4$ & $2.6 \pm 0.72(5)$ & $61 \pm 17$ \\
\hline Citrate synthase & $38 \pm 12.9(8)$ & $118 \pm 40^{* * *}$ & $14.4 \pm 1.4(5)$ & $339 \pm 33$ \\
\hline Fumarase & $294 \pm 42 \cdot 0(4)^{* * *}$ & $911 \pm 130^{* *}$ & $12 \cdot 5 \pm 1 \cdot 19(5)$ & $294 \pm 28$ \\
\hline $\begin{array}{l}\text { Malate dehydrogenase } \\
\text { 2-Oxoglutarate }\end{array}$ & $167 \pm 14.8(9)^{* * *}$ & $518 \pm 46^{* * * *}$ & $45 \pm 2.8(5)$ & $1072 \pm 67$ \\
\hline dehydrogenase & $1.0 \pm 0.19(4) \ddagger$ & $3 \cdot 1 \pm 0 \cdot 6^{*}$ & $2.0 \pm 0.77(4)$ & $48 \pm 18 \cdot 2(4)$ \\
\hline Cytochrome $\mathrm{c}$ oxidase & $7.2 \pm 1.94(3)^{* *} \ddagger$ & $22 \cdot 3 \pm 6 \cdot 0^{* *}$ & $26 \pm 3 \cdot 7(4)$ & $615 \pm 86.5(4)$ \\
\hline Carnitine acetyl transferase & $11.6 \pm 1.29(12)^{* * *}$ & $36 \pm 4 \cdot 0^{* * *}$ & $30 \pm 0.9(4)$ & $717 \pm 22$ \\
\hline
\end{tabular}

Values are means \pm s.e.m. for spermatozoa from individual ejaculates or rats except for the values indicated by $\ddagger$ for which pooled material was used and the no. of observations is indicated. ND, Not detected.

Values significantly different from those for rat spermatozoa; ${ }^{*} P<0.05,{ }^{* *} P<0.01,{ }^{* * *} P<0.001$ ( $t$ test).

$\dagger 1 \mathrm{mg}$ protein $=32.3 \times 10^{6}$ human spermatozoa or $4.24 \times 10^{6}$ rat spermatozoa.

\section{Discussion}

The data presented above confirm the conclusion of Suter et al. (1979) that washed human spermatozoa can obtain enough energy from the respiration of endogenous substrates to remain motile and to maintain the ATP concentration in the cell. However, neither oligomycin nor CCCP had a significant effect on the oxygen uptake although either $0.4 \mu \mathrm{M}$-CCCP or 8 
$\mu \mathrm{M}$-oligomycin decreased the ATP concentration in the spermatozoa and $0.4 \mu \mathrm{M}$-CCCP increased the production of ${ }^{14} \mathrm{CO}_{2}$ from $\left[\mathrm{U}-{ }^{14} \mathrm{C}\right]$ glucose, This suggests that although respiration is coupled to oxidative phosphorylation the linkage is loose or only applied to a part of the oxygen uptake. The oxidation of succinate was not coupled since succinate did not relieve the effect of rotenone on the ATP concentration. The discrepancies in the literature suggest that the tightness of coupling is affected by the experimental conditions but it is unclear which factors may be important.

The role of the tricarboxylic acid cycle in limiting the respiratory rate of human spermatozoa is also obscure. The entry of substrates into the citric acid cycle did not limit oxidation (Peterson $\&$ Freund, 1974) and the activities of the enzymes of the cycle reported above are more than adequate to explain the observed rate of oxygen uptake. It has been proposed that the activity of 2-oxoglutarate dehydrogenase limits flux through the tricarboxylic acid cycle in muscle (Read et al., 1977). This is the least active of the enzymes assayed in human spermatozoa but its activity would permit an oxidation uptake of about $12.5 \mathrm{nmol} \mathrm{O}_{2} / 10^{8} \mathrm{cells} / \mathrm{min}$ at $35^{\circ} \mathrm{C}$ based on the complete oxidation of acetyl $\mathrm{CoA}$ via the cycle and assuming a $Q_{10}$ of 2 . Cytochrome c oxidase is much less active in human spermatozoa than in rat spermatozoa and this could be a factor in explaining the lower respiratory activity of the former cells. However, great caution is needed in interpreting enzyme activities measured in vitro since the amount detected is very dependent on the extraction conditions used. The activities reported above for isocitrate dehydrogenase (NAD), 2-oxoglutarate dehydrogenase and fumarase in rat spermatozoa are much greater than those found by Brooks (1977). This is probably because we included $0.1 \%$ Triton X-100 in the extraction media but did not include a low speed centrifugation step before assaying the homogenates. The activities given by Brooks (1977) would not be adequate to explain the rate of respiration by rat epididymal spermatozoa in the presence of added substrates (Ford \& Waites, 1980).

Sodium arsenite was expected to inhibit both pyruvate dehydrogenase (EC 1.2.4.1) and 2-oxoglutarate dehydrogenase (Webb, 1966) and its effect was specific since it did not significantly decrease the production of lactate from glucose or the ability of the spermatozoa to obtain ATP from this process. Since the pyruvate pool in human spermatozoa is very small (W. C. L. Ford \& A. Harrison, unpublished data), an effect of arsenite on the ATP concentration would imply that there is a flux through 2-oxoglutarate dehydrogenase in the absence of added glucose. However, the size of this effect was very variable between experiments.

Malonate is a classical inhibitor of succinic dehydrogenase (Webb, 1966) and its effect in these experiments indicates that the production of ATP by the oxidation of endogenous substrate and the oxidation of glucose to $\mathrm{CO}_{2}$ do not involve succinate oxidation. Possibly $\mathrm{CO}_{2}$ could be produced by the dismutation of pyruvate (Peterson \& Freund, 1974) but if substrate continued to enter the cycle then a source of oxaloacetate would be needed. Alternatively a pool of succinate dehydrogenase inaccessible to malonate could exist.

Our results suggest that a weak Pasteur effect may be demonstrable in human spermatozoa because slightly more lactate was produced from glucose in the presence of respiratory inhibitors. This conflicts with previous observations (Peterson \& Freund, 1970) and the data are by no means conclusive. However, it is now clear that human spermatozoa can obtain energy from respiration although several anomalies remain to be explained about the pathways involved. The amount of substrate transformed by respiration is small compared to the flux through the glycolytic pathway, but the net yield of ATP is similar or even greater from the former route so its physiological significance may be greater than is generally appreciated.

We thank the student volunteers for providing the semen samples and Dr A. D. G. Gunn, Mrs J. C. Robinson and Miss A. Collen of the University Health Centre for arranging their collection. This work was supported by grant Nos. 75311 and 77127 from the World Health Organization. 


\section{References}

Alp, P.R., Newsholme, E.A. \& Zammit, V.A. (1976) Activities of citrate synthase and $\mathrm{NAD}^{+}$linked and $\mathrm{NADP}^{+}$linked isocitrate dehydrogenase in muscle from vertebrates and invertebrates. Biochem. J. 154, 689-700.

Bergemeyer, H.U. \& Bernt, E. (1963) Malic dehydrogenase. In Methods of Enzymatic Analysis, pp. 757-760. Ed. H. U. Bergemeyer. Academic Press, New York.

Brooks, D.E. (1977) Activity and androgenic control of enzymes associated with the tricarboxylic acid cycle, lipid oxidation and mitochondrial shuttles in the epididymis and epididymal spermatozoa of the rat. Biochem. J. 174, 741-752.

Chulavatnatol, M. \& Haesungcharern, A. (1977) Stabilization of adenylate energy charge and its relation to human sperm motility. J. biol. Chem. 252, 8088-8091.

Cleland, W.W., Thompson, V.W. \& Bardon, R.E. (1969) Isocitrate dehydrogenase (TPN-specific) from pig heart. In Methods in Enzymology, Vol. 13, pp. 30-34. Ed. J. M. Lowenstein. Academic Press, New York.

Dawson, R.M.C., Elliott, D.C., Elliott, W.H. \& Jones, K.M. (1969) Data for Biochemical Research, pp. 625-626. Clarendon Press, Oxford.

Edwards, E.M., Dacheux, J.-L. \& Waites, G.M.H. (1976) Effects of $\alpha$-chlorohydrin on the metabolism of testicular and epididymal spermatozoa of rams. $J$. Reprod. Fert. 48, 265-270.

Eliasson, R. (1970) Oxygen consumption of human sperm. Biol. Reprod. 3, 369-374.

Ford, W.C.L. \& Waites, G.M.H. (1978) A reversible contraceptive action of some 6-chloro-6-deoxysugars in the male rat. J. Reprod. Fert. 52, 153-157.

Ford, W.C.L. \& Waites, G.M.H. (1980) The control of male fertility by 6-chloro-6-deoxysugars. Reprod. Nutr. Devel. 20, 1101-1110.

Ford, W.C.L., Harrison, A., Takkar, G.L. \& Waites, G.M.H. (1979) Inhibition of glucose catabolism in rat, hamster, rhesus monkey and human spermatozoa by $\alpha$-chlorohydrin. Int. J. Androl. 2, 275-288.

Harrison, R.A.P. (1976) A highly efficient method for washing mammalian spermatozoa. J. Reprod. Fert. 48, 347-353.

Hicks, J.J., Martinez, M., Pedron, N. \& Rosado, A. (1972) Metabolic changes in human spermatozoa related to capacitation. Fert. Steril. 23, 172-179.

Hill, R.L. \& Bradshaw, R.A. (1969) Fumarase. In Methods in Enzymology, Vol. 13, pp. 91-99. Ed. J. M. Lowenstein. Academic Press, New York.

Hohorst, H.J. (1963) L(+)-Lactate. In Methods of Enzymatic Analysis, Vol. II, pp. 266-270. Ed. H. U. Bergemeyer. Verlag Chemie, Weinheim.

Macleod, J. (1941a) The metabolism of human spermatozoa. Am.J. Physiol. 132, 193-201.

Macleod, J. (194 Ib) The effect of glycolysis inhibitors and of certain substrates on the metabolism and motility of human spermatozoa. Endocrinology 29, 583-591.

Macleod, J. (1943) The role of oxygen in the metabolism and motility of human spermatozoa. Am. J. Physiol. 138, 512-518.

Mann, T. (1951) Studies on the metabolism of semen. 7. Cytochromes in human spermatozoa. Biochem. $J$. 48, 386-388.

Murdoch, R.N. \& White, I.G. (1968) Studies on the metabolism of human spermatozoa. $J$. Reprod. Fert. 16, 351-359.

Nevo, A. (1966) Relation between motility and respiration in human spermatozoa. J. Reprod. Fert. 11 , 19-26.

Pearson, D.J., Chase, J.F.A. \& Tubbs, P.K. (1969) The assay of (-)carnitine and its $\mathrm{O}$-acyl derivatives. In Methods in Enzymology, Vol. XIV, pp. 612-622. Ed. J. M. Lowenstein. Academic Press, New York.

Peterson, R.N. \& Freund, M. (1968) An evaluation of the respiratory capacity of human spermatozoa. $J$. Reprod. Fert. 17, 357-372.

Peterson, R.N. \& Freund, M. (1969) Glycolysis by washed suspensions of human spermatozoa. Biol. Reprod. 1, 238-246.

Peterson, R.N. \& Freund, M. (1970) ATP synthesis and oxidative metabolism in human spermatozoa. Biol. Reprod. 3, 47-54.

Peterson, R.N. \& Freund, M. (1974) Citrate formation from exogenous substrates by washed human spermatozoa. J. Reprod. Fert. 38, 73-79.

Plaut, G.W.E. (1969) Isocitrate dehydrogenase (DPNspecific) from bovine heart. In Methods in Enzymology, Vol. 13, pp. 34-42. Ed. J. M. Lowenstein. Academic Press, New York.

Read, G., Crabtree, B. \& Smith, G.H. (1977) The activities of 2-oxoglutarate dehydrogenase and pyruvate dehydrogenase in hearts and mammary glands from ruminants and non ruminants. Biochem. J. 164, 349-355.

Schmidt, E. (1963) Glutamate dehydrogenase. In Methods of Enzymatic Analysis, pp. 752-756. Ed. H. U. Bergemeyer. Academic Press, New York.

Storey, B.T. (1978) Effect of ionophores and inhibitors and uncouplers of oxidative phosphorylation on sperm respiration. Arch. Androl. 1, 69-78.

Suter, D., Chow, P.Y.W. \& Martin, I.C.A. (1979) Maintenance of motility in human spermatozoa by energy derived through oxidative phosphorylation and addition of albumin. Biol. Reprod. 20, 505-510.

Terner, C. (1960) Oxidation of exogenous substrates by isolated human spermatozoa. Am. J. Physiol. 198, 48-50.

Webb, J.L. (1966) Enzyme and Metabolic Inhibitors. Academic Press, New York.

Wilkinson, G.N. (1961) Statistical estimations in enzyme kinetics. Biochem. J. 80, 324-332.

Williamson, J.R. \& Corkey, B.E. (1969) Assays of intermediates of the citric acid cycle and related compounds by fluorimetric enzyme methods. In Methods in Enzymology, Vol. 13, pp. 434-513. Ed. J. M. Lowenstein. Academic Press, New York.

Yonetani, T. (1967) Cytochrome oxidase. Beef heart. In Methods in Enzymology, Vol. 10, pp. 332-335. Eds R. W. Estabrook \& M. E. Pullman. Academic Press, 